\title{
Investigative Subject
}

National Cancer Institute

\section{Source}

National Cancer Institute. Investigative Subject. NCI Thesaurus. Code C79916.

An entity, either biologic or otherwise, of interest in an investigation. 